INTERNATIONAL JOURNAL OF ENVIRONMENT

Volume-2, Issue-1, Sep-Nov 2013

ISSN 2091-2854

Received: 14 September

Revised: 20 October

Accepted: 28 October

\title{
SCENARIO OF SOLID WASTE MANAGEMENT IN HETAUDA MUNICIPALITY, NEPAL
}

\author{
Bigyan Neupane ${ }^{1 *}$ and Shuvee Neupane ${ }^{2}$ \\ ${ }^{1}$ Environmental Officer, Environmental Resources Group Pvt. Ltd. \\ ${ }^{2}$ Public Relation and Project Implementation Officer, Abhiyantra Consulting Pvt. Ltd. \\ *Corresponding author: nbigyan@ hotmail.com
}

\begin{abstract}
The paper aims to enlighten the solid waste management of Hetauda Municipality in Makwanpur district of an area of $44.5 \mathrm{sq} . \mathrm{km}$. The total human population of the municipality is 84,671 (CBS 2011). Out of 11 wards, 5 wards (1, 2, 3, 4 and 10) were selected for the present study. In total 50 households, 10 institutions and 10 commercial sectors were selected from studied wards from which samples of different types of wastes were collected, segregated and weighed. Weight was calculated using a digital spring balance and a bag $0.043 \mathrm{~m}^{3}$ was used for the estimation of volume. Organic wastes were found to be dominant in the household $(51.73 \%)$ and commercial sectors $(61.70 \%)$ whereas in institutions, plastic $(50.36 \%)$ and papers $(38.19 \%)$ were prevailing. The findings revealed that per capita $155.4 \mathrm{gm} /$ person/day household waste was generated in Hetauda Municipality. The residents are also aware of the harmful effects of the wastes, and demand an effective solid waste management services. Though they are aware about the sustainable management of wastes, due to erratic collection of wastes, some of them throw the wastes in the open lands - The local people also participate in the awareness campaigns organized by local NGOs and municipal. Solid waste management strategies are timely need for an effective management of anthropogenic wastes. Regular waste collection, improvement of dumping sites and sufficient number of composting plants are recommended in the municipality.

Keywords: Hetauda municipality, Solid waste management, Landfill site, Management strategies, Nepal
\end{abstract}

\section{Introduction}

Industrialization and Urbanization has led to numerous problems from over exploitation of natural resources to increment in the amount of waste production. The increase in the population and the change in the lifestyle of the people have led to high daily consumption pattern leading to even higher production of solid waste (Thapa and K.C., 2011). It is expected that, the solid waste production in Asia would reach around 1.8 million tons per day in 2025 (Pokharel and Viraraghavan, 2005).

Like the other developing countries, Nepal is not aloof of this problem. In accordance with the enactment of local self-governance act (1999), municipalities are the responsible authorities for the management of solid wastes (Thapa and K.C., 2011). Since then, they are taking care of the wastes generated by the respective municipalities with the available resources. Although, small urban centers have been declared municipalities, they have been 
constantly suffering from the lack of infrastructural, financial and technical resources for the management of wastes (Water Aid, 2008).

This paper aims to highlight the type of the solid wastes generated and the practices of Solid Waste Management (SWM) in Hetauda Municipality of Nepal reflecting the present scenario of other municipalities of Nepal.

The present research was carried out in Hetauda municipality, Nepal. Hetauda is a mid-sized municipality with an area of $47.77 \mathrm{~km}^{2}$. It is located in mid-south of Nepal, $225 \mathrm{~km}$ from Kathmandu. It is divided into 11 wards (Practical Action, 2008). Hetauda municipality was established in 1969, and consists of 11 wards of which 1, 2, 3, 4, 5, 9 and 10 are located in urban areas. Ward 6 is in semi-urban area and remaining wards 7,8 and 11 are in rural pockets. The study area $\left(27^{\circ} 25^{\prime} 0^{\prime \prime} \mathrm{N}, 85^{\circ} 2^{\prime} 0^{\prime \prime} \mathrm{E}\right)$ falls in sub-tropical region, intermingled into Chure and Mahabharat ranges. Hetauda is 300 to $390 \mathrm{~m}$ above mean sea level $(\mathrm{ms} 1) .23 \%$ of the municipality is covered by forest, $45 \%$ agricultural area, $11 \%$ residential, $10 \%$ industrial, $7 \%$ urban and $4 \%$ is other (Hetauda Municipality Office, 2012).

Residential settlements are clusters in urban areas whereas semi urban/rural areas exist as sparsely populated. Commercial settlements are located on the main road along the highway. Shops dominate the commercial settlements with patchy localities of hotels and restaurants in the urban areas. Industrial area is known as Hetauda Industrial District (HID).

There is one landfill site located in Bhutandevi Community Forest occupying 27,085 sq. $\mathrm{m}$ of land. About 10 tons of waste is disposed of at a distance of $1.5 \mathrm{~km}$ from the main city. Such practice is under operation since 2058 (Hetauda Municipality Office, 2012).

The study was conducted in selected wards $(1,2,3,4$ and 10) of the municipality.

\section{Methodology}

The study was carried out in 5 wards of Hetauda municipality, divided into three groups (household, commercial and institutions). For the collection of data, samples of wastes were procured from ten households, one hotel-restaurant, shop, school-college and government/ non-government office each from selected ward.

For effective sampling, following steps were carried out:

- Profile of each ward was studied by regular visit to the respective w ard.

- Settlement pattern was observed and delineated in each locality

- For the household survey, economic and social status of inhabitants was estimated

- For evaluating the pattern of settlement, each house was chosen to get representative sample of the study area.

For the primary data collection, standard questionnaires were used for interviewing the people inhibiting the selected sites. At the same time, the wastes generated at sites in 24 hours were weighed using spring balance. Later, the wastes were segregated into chief components which were weighed again. The secondary data was collected from Hetauda municipality office. To study quality control and assurance, the measurement was repeated until the consistent results were obtained. Also, the questionnaire form was repeatedly checked to reduce the error.

\section{Results and discussion}

Food waste (organic) were dominant in the household of Hetauda Municipality which was around 51\%. Plastic and paper/ paper products were generated around $15 \%$ and $27 \%$ respectively. Remaining $7 \%$ constituted of glass and some metals and textiles 
(Figure 4).

Another source of waste generation was commercial complex. Commercial wastes were generated mostly from hotels and restaurants which included organic waste in huge amount. The organic waste included large amount of vegetable products produced during the making of food whereas the leftover food was also dominant. After organic waste, plastic, paper and metal cans were generated as commercial waste (Asian Development Bank, 2013).

School/colleges and office falls under institutional category, institutional waste consisted mostly of paper $(38 \%)$ and plastic $(33 \%)$. Here organic wastes were very less in quantity. Organic wastes were seen in some office where they run canteen (Asian Development Bank, 2013).

The domestic waste varied in each household and each ward. The highest domestic waste was found in ward number 4 . Figure 1 shows the waste from individuals' households from each ward.

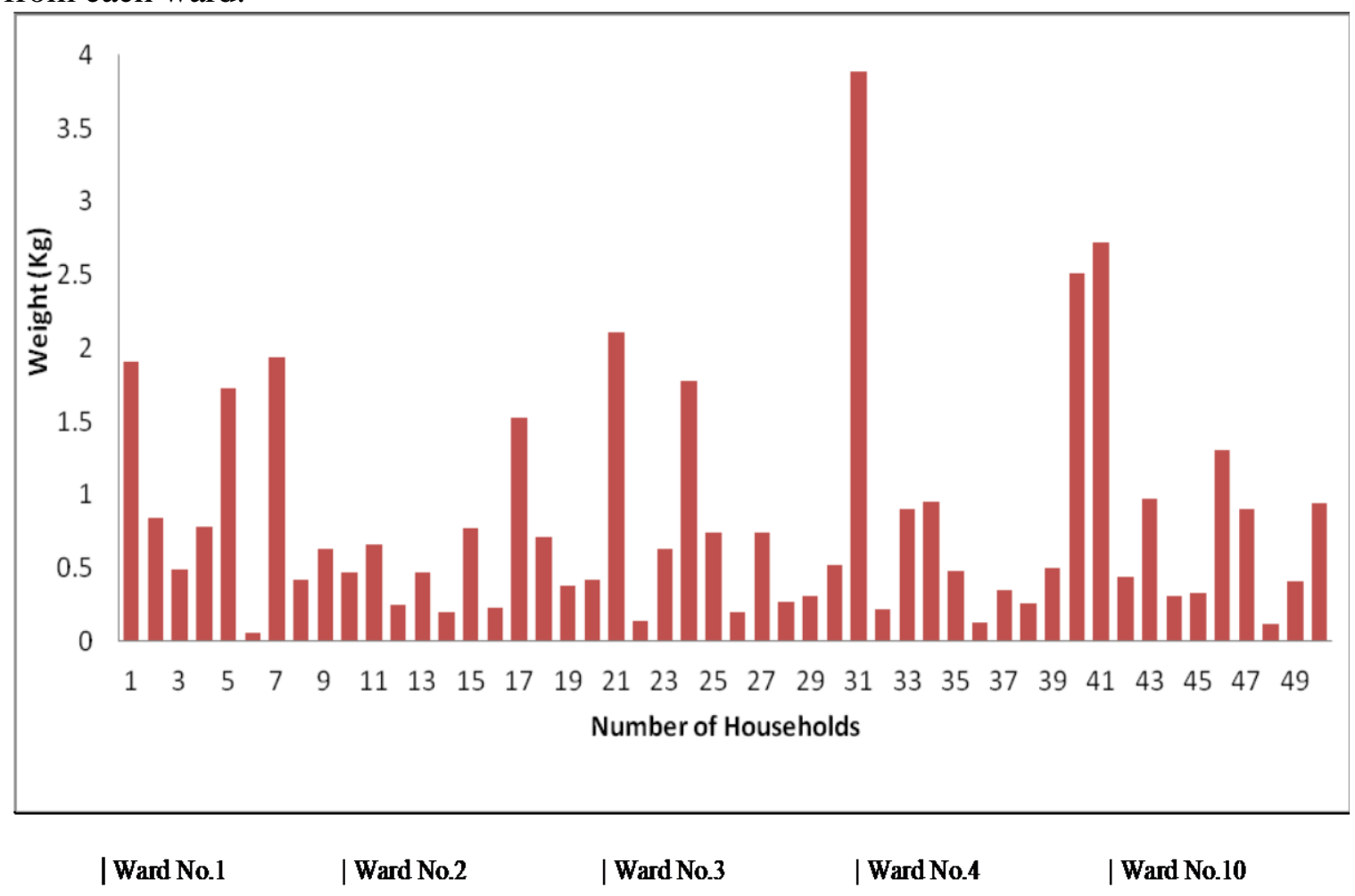

Figure 1: Waste generated from individual household

Of 50 households, there were 262 people and the total waste from these 50 household was $40.73 \mathrm{~kg} /$ day. Therefore, average per capita waste generation is $0.15 \mathrm{~kg} /$ person/day which is less than the waste production in the Kathmandu metropolitan city (0.39kg/person/day) (SWMRMC, 2006).

From the municipality with five wards, total generation and average composition of household is shown in Figure 2 and Figure 3 respectively. 


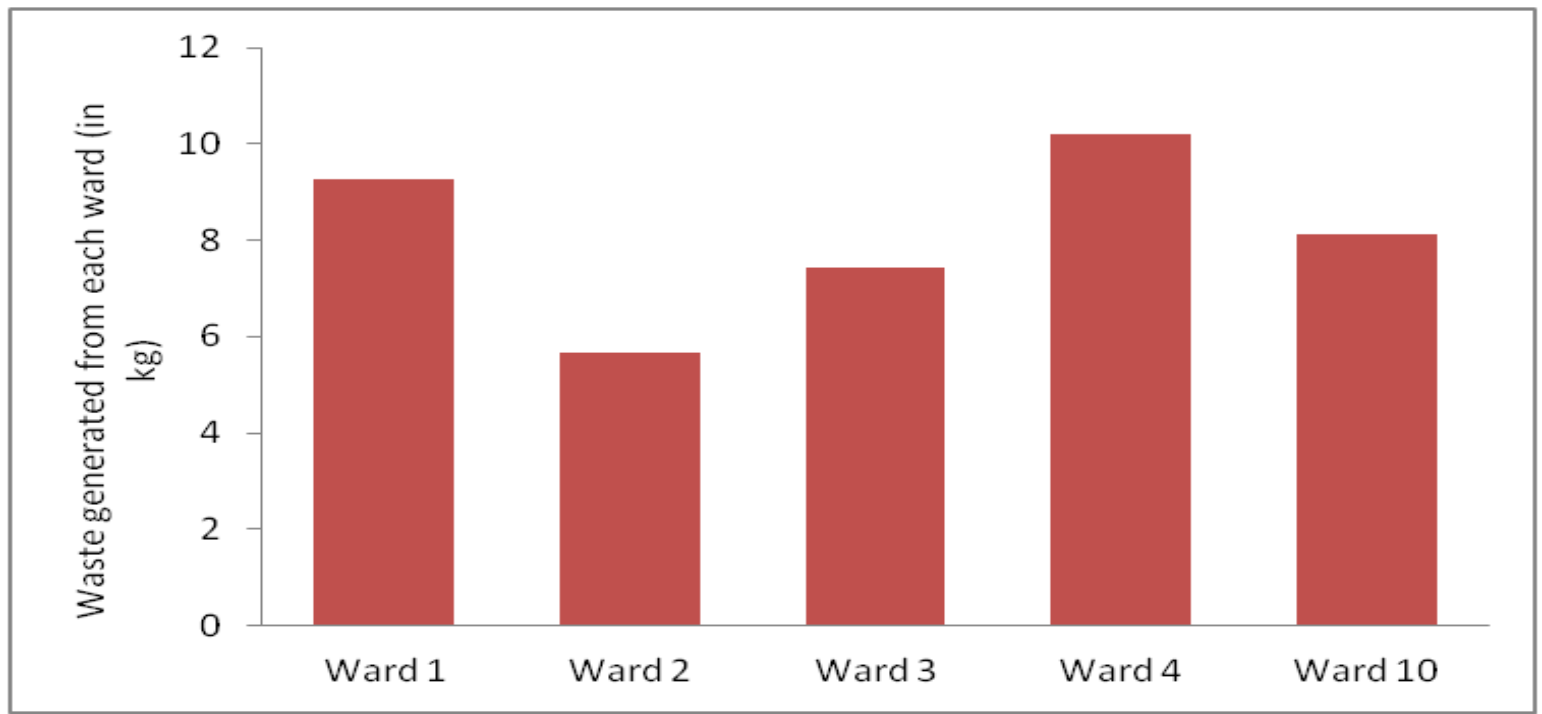

Figure 2: Waste generated from each ward

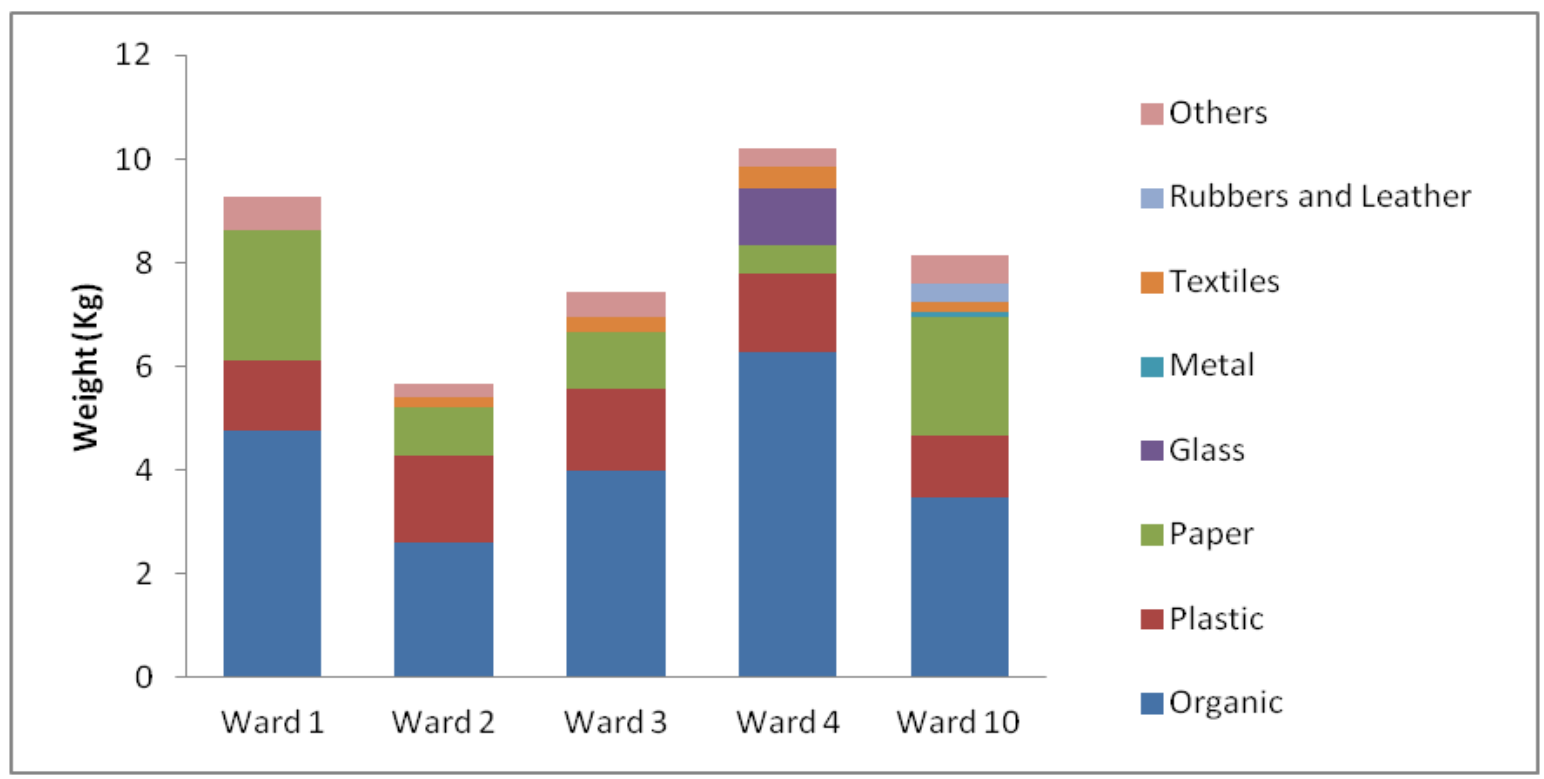

Figure 3: Composition and weight of Household Waste

From the municipality with five wards, total waste generation and average composition from the institutions is shown in Figure 4 and Figure 5 respectively. 


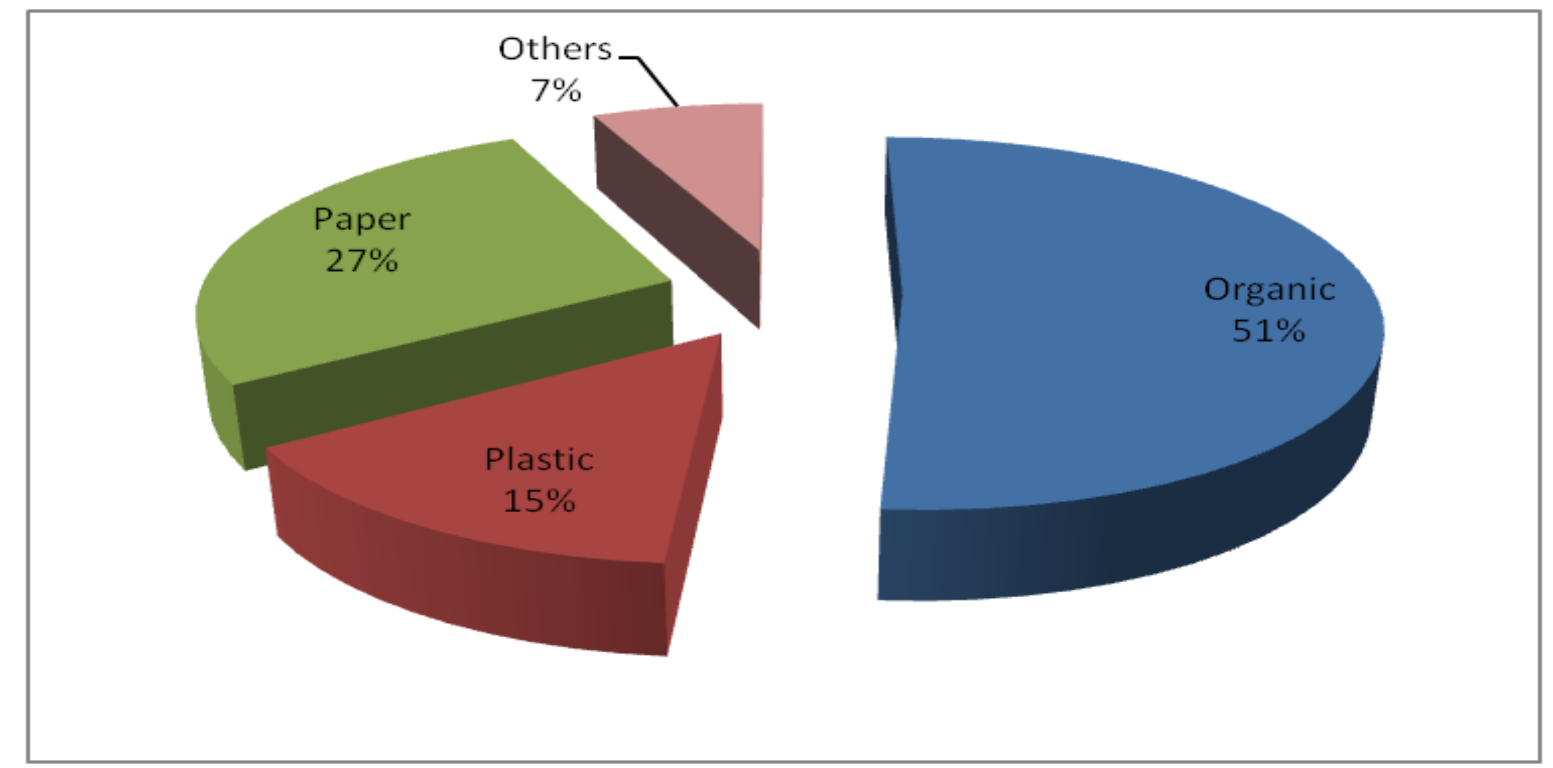

Figure 4: Average composition of Domestic waste: Municipality

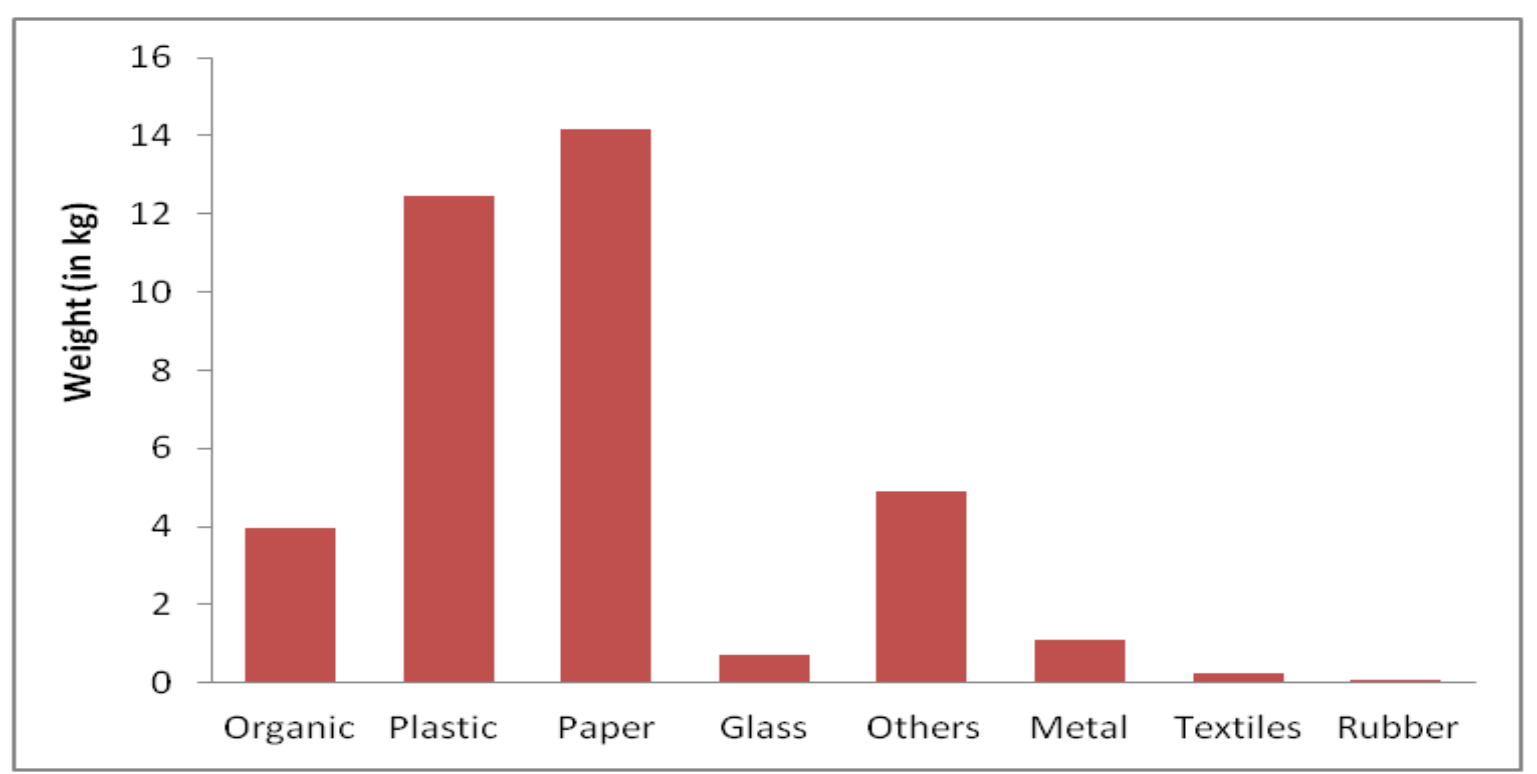

Figure 5: Waste generated from Institution: Municipality

Similarly, the waste generation from the commercial sector and its average composition has been illustrated in Figure 6, 7 and 8 respectively. 


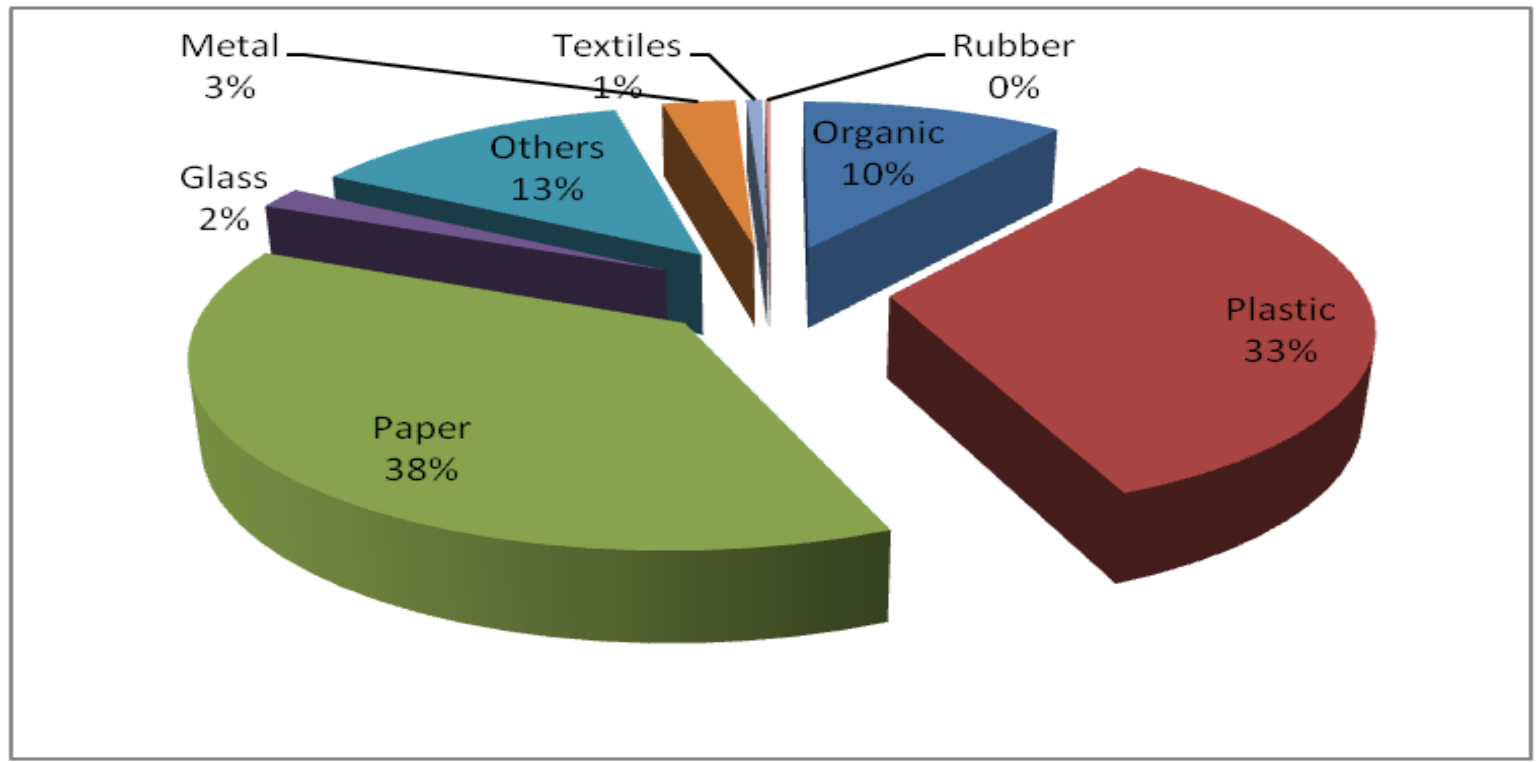

Figure 6: Average Composition from Institution: Municipality

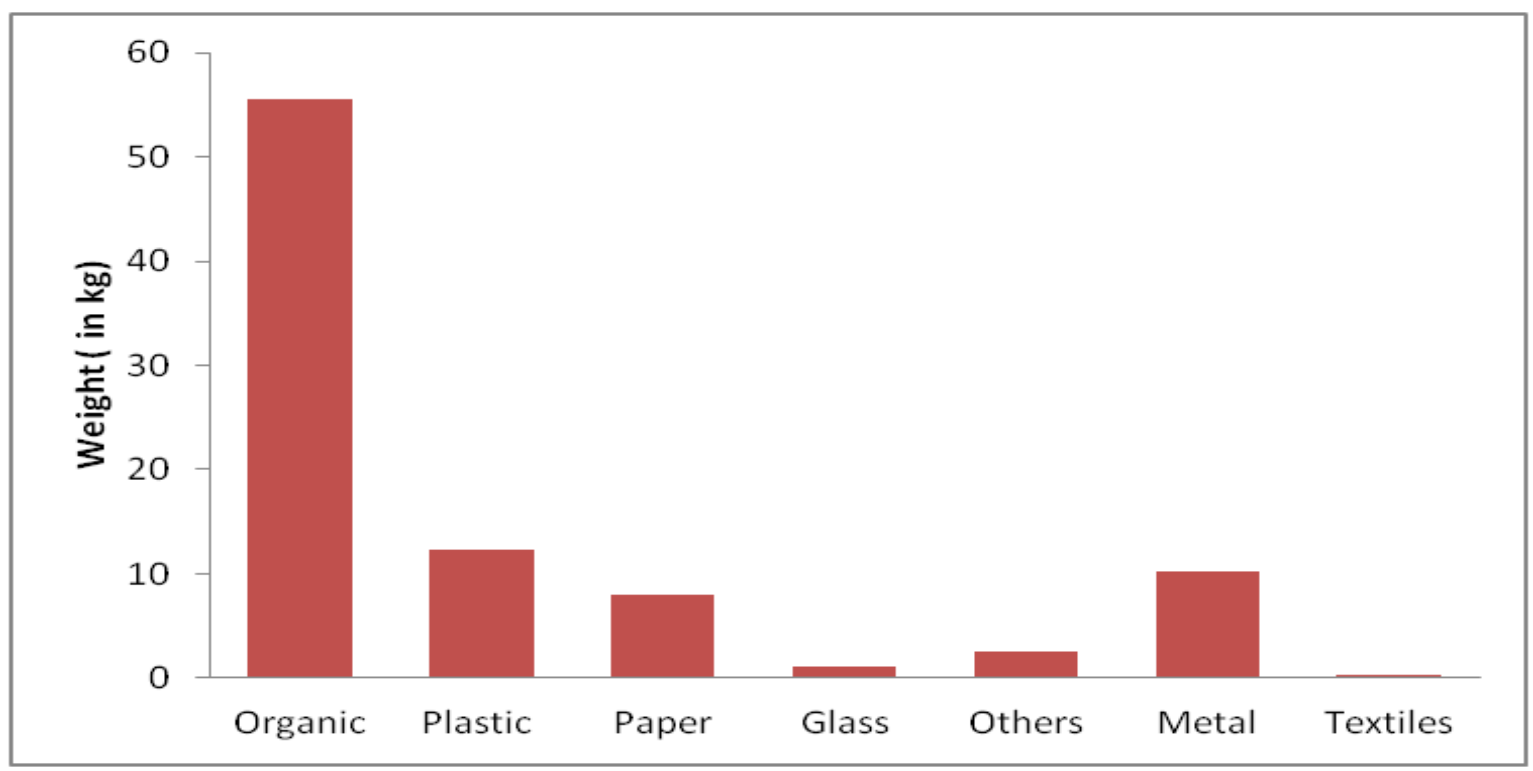

Figure 7: Waste generated from Commercial Sector: Municipality 


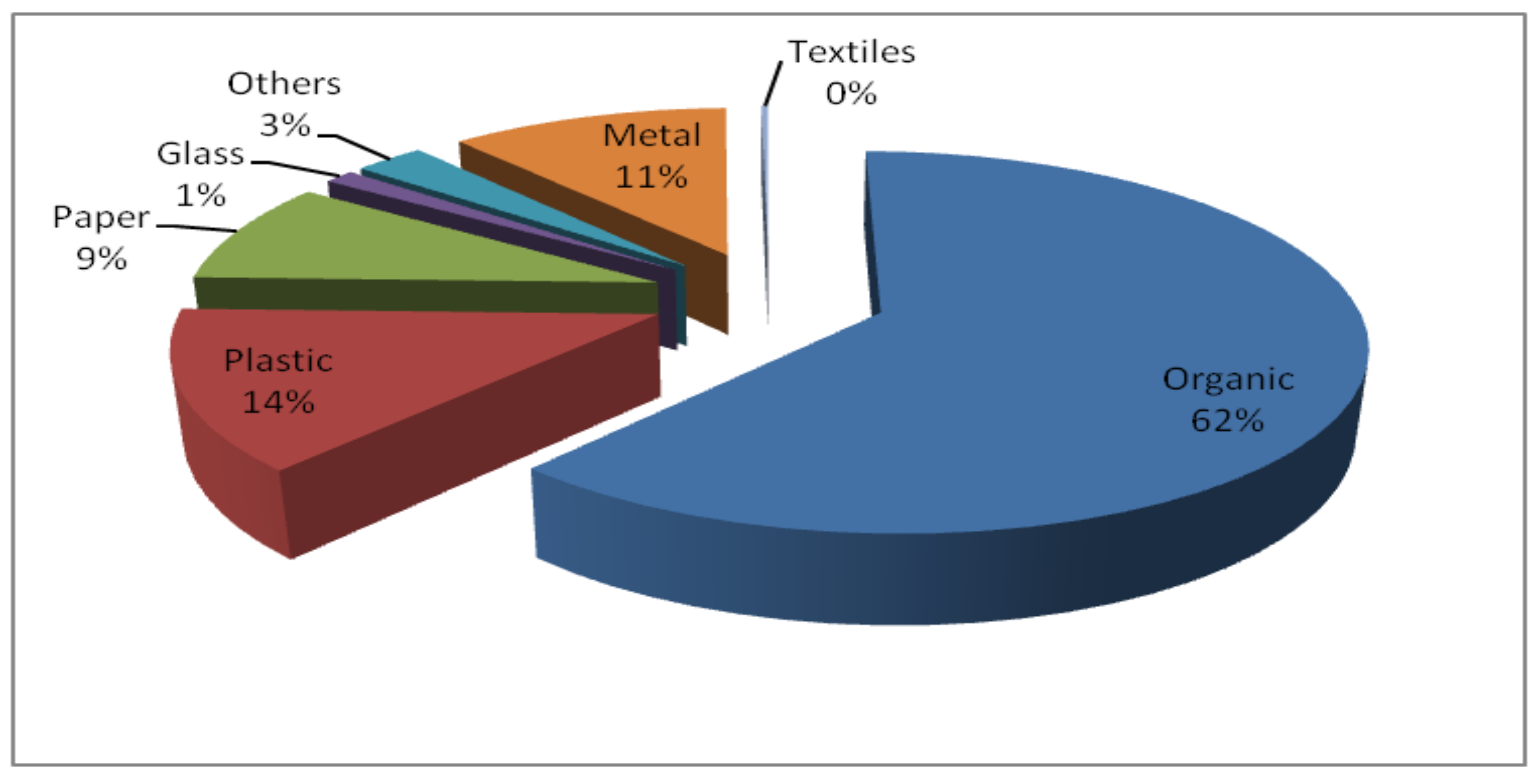

Figure 8: Average composition from Commercial Sector: Municipality

\section{Existing solid waste management system}

Solid waste management in Hetauda is done by Hetauda Municipality office in correspondence with two organizations named Green and Clean City and Clean the Nepal. Collection practice in every ward is different. In some wards, the collection of waste is done on alternate days or in the difference of two days whereas in some wards the collection is done once a week. For household, the above mentioned organizations are responsible for collection of the waste.

In the market and commercial complex, municipality bears the responsibility for collection and disposal. The municipality office offers service in wards 1, 2, 3, 4, 5 and 10 . In the remaining wards municipality provides service once or twice a month. House adjacent to the road also gives away their waste to the municipality truck. Existing waste generation pattern can be summarized as in Table 1 and the details have been described below.

Table 1: Waste generation pattern

\begin{tabular}{|l|l|l|}
\hline SN. & Type & Amount (tons/day) \\
\hline 1 & Domestic waste & 2.2 \\
\hline 2 & Commercial waste & 2.2 \\
\hline 3 & Institutional waste & 2.33 \\
\hline 4 & Industrial waste & 2.3 \\
\hline
\end{tabular}

\section{Collection and segregation}

For the collection of the waste that is generated from households, commercial buildings and institutions, the municipality truck/ tractor is used early in the morning. Door to door collection system has been implemented using tricycles (Practical Action, 2008). Street sweeping is done side by side during the collection of waste and the collected waste from the street is also carried by the truck/ tractor. All the wastes are taken in the same vehicle and segregated in the landfill site. Previously, metal containers had been used in order to improve the efficiency of the collection operation. However, the local people rejected this method of storage because of the unpleasant smell coming from the containers and the scattering of waste around the container by animals (Hetauda Municipality, 2012). 
Source segregation is commonly not practiced in household. There are very few houses where the segregation is done beforehand.

\section{Primary transportation and transfer station}

For primary transportation in the household, Green and Clean City and Clean the Nepal are mobilized in the local level. Green and Clean City has a rickshaw/cart for the collection of solid waste. It has 6 carts and carries 24 lots of waste (times) in average. Another organization Clean the Nepal has 1 tractor and 1 cart for the collection. There is no transfer station. So, all the wastes are directly carried to the landfill site directly.

\section{Final transportation and disposal method}

After the collection of the waste, it is taken to the dumping site. Dumping site is located in ward number 10. The place is nearby Rapti River and called Rapti Bagar and the area is located in forest area of Bhutandevi. The existing equipments for final disposal are bulldozers, tractor/ power tiller, tipper/dump trucks and water tanker (Hetauda Municipality, 2012).

In the landfill site, the waste is segregated and is dumped. The waste is compacted manually and for proper compaction, water tanker is used. Since open dumping is the way of disposal, there is a problem of haphazard scavengers and animals entering the site. Another problem in the site is leachate.

\section{Resource recovery methods \\ Recycling}

Recycling and reuse practice is not seen in the household level. All the waste generated is discarded and sent for disposal. However, there are around 100 scrap dealers (kawadi) who collect recyclable products which is around $300 \mathrm{~kg} / \mathrm{day}$ which has around $150 \mathrm{~kg}$ of plastics per day. The types of materials mostly being recycled are plastic, papers, glasses and metals.

\section{Composting}

Composting in the household level is seen in the households having abundant space. They normally dig a pit and keep organic waste so that they could use it as compost in their field. However there are no composting plants on the community level.

Composting plant in the municipality has been constructed in ward no. 10 in Bhutandevi forest of 3 tons capacity. It is at the distance of $1.5 \mathrm{~km}$ from the main city and is in the phase of operation.

\section{Special waste management}

Special wastes such as hospital waste, slaughterhouse, toxic and hazardous waste are disposed and treated by the concerned agencies themselves. They burn the waste using incinerators. The benefit of self-treatment is that the toxic waste does not mix up with the solid waste and it does not have impact on the human life and also does not have negative impact on the land fill site. However, if the hazardous/toxic waste not well treated and if complete combustion is not done; it produces harmful gases causing impact on humans and environment.

\section{Public awareness and community mobilization}

Public awareness program had been conducted by private organization in the municipality in collaboration with the local leaders several times. Although programs were conducted, many 
people seemed unaware of such programs. However, there has been some positive change in the behavior of the people as they have started to dispose their waste in a proper and prescribed place. Moreover, municipality has declared some places as plastic bags prohibited area which is quite appreciable.

\section{Problems and issues of the existing SWM practice}

\section{Sustainability of the system}

The door to door service has been started since seven years. Also from big commercial complex and institutions, huge amount of waste are generated. The waste carrying vehicle could not carry all the waste at a time. Since, only one dumping site exists, it is difficult to manage the waste.

\section{Issues related to dumping /landfill site}

There is only one dumping and all the waste is dumped there. Since it is open dumping, the entry of scavengers and animals is a great problem. Above all, there's a problem of leaching. If well managed, the life span of landfill site is around thirty years but if the existing way continues, the life span is estimated for ten years.

On legal basis, the area of landfill site is facing court petition. Since the land belongs to the community forest, the users have filed a case in the court against the construction of landfill (Hetauda Municipality, 2012).

\section{Conclusion}

A baseline survey was conducted to explore the status of Solid Waste Management situation in Hetauda Municipality. From the survey it was found that the major percentage of the waste included organic waste that could be composed. Various methods of reduction of the waste such as reuse and recycling has been promoted in the municipality. However due to the lack of infrastructures and the manpower, much needs to done for the effective solid waste management of the area.

\section{Recommendation}

Through the study conducted in the Hetauda Municipality, the status of solid waste management was analyzed and the following recommendations are made to the best of authors' knowledge:

- Frequency of the waste collection practice should be increased;

- Throwing waste in a nearby open field should be discouraged;

- Since many wards are at a little far distance from the municipal office, the SWM authority can hand the responsibility to the ward offices and they can manage the household waste of respective wards;

- If possible, each ward could have a community composting facilities; else at least sufficient number of composting plant could be established;

- Each ward should be provided with waste collection container and a certain transporting/disposal mechanism;

- Educating people and encouraging them to manage the organic waste at household level;

- Increase of helping hand is needed to minimize waste;

- Personnel for SWM service must be increased and it would more beneficial if local people could be hired in each ward. 


\section{Acknowledgement}

We would like to express our sincere thanks to all the team members of Solid Waste Management Technical Support Center (SWMTSC) for their guidance and support throughout this study. Besides, we would like to thank officials from Hetauda Municipality Office for providing valuable information and suggestion. Also, we would like to show our gratitude towards Asian Development Bank (ADB) for their technical assistance and all those who helped continuously till the completion of the project.

\section{References}

Thapa, B. \& K.C., A. (2011). Solid waste management in landfill sites of Nepal. Indian Journal of Science and Technology, 4(3), 164- 170.

Pokhrel, D. Viraraghavan, T. (2005). Municipal solid waste management in Nepal: practices and challenges. Waste Management, 25(5), 555-562.

Water Aid. (2008). Solid waste management in Nepal.

Practical Action. (2008). Best practices on solid waste management of Nepalese cities

Hetauda Municipality Office. (2012). Hetauda Municipality. Retrived on May 2012 from http://www.hetaudamun.gov.np.

Asian Development Bank. (2013). Municipal solid waste generation and composition: current status and policy recommendations.

Solid Waste Management and Resource Mobilization Center. (2006). Solid Waste Management in the Municipalities of Nepal. Government of Nepal. 